\title{
A Note on Primary Material
}

This collection re-publishes articles on anti-colonialism from a number of remarkable left-wing African American magazines and Communist Party publications of the interwar period:

The Communist [1919-1921] a weekly magazine of the Communist Party of America (CPUSA) edited by Italian-born Communist Louis C. Fraina.

The Communist [1927-1944] a theoretical monthly magazine of the CPUSA which was renamed Political Affairs in 1944. Its original editor was the German-born Communist Max Bedacht. The magazine is notable for its long and often exhaustive articles.

The Crisis [1910-present] the monthly magazine of the National Association for the Advancement of Colored People (NAACP) edited by W. E. B. Du Bois until 1934 when Roy Wilkins became editor. In addition to its campaigning journalism The Crisis also had extensive arts and culture coverage.

The Crusader [1918-1922] a monthly newspaper founded by Cyril Briggs in 1918, which eventually became the magazine of the African Blood Brotherhood (ABB). Briggs was a founding member of the ABB, went on to join the Communist Party and edited The [Negro/Harlem] Liberator (1929-1935).

The Emancipator [1920] was launched in March 1920 and edited by the Jamaican Socialist W. A. Domingo (1889-1968). It was a short-lived publication, closing down on 24 April 1920.

The [Harlem/Negro] Liberator [1929-1935] a weekly and bi-weekly newspaper of the American Negro Labor Congress edited by Cyril Briggs until September 1933 (subsequently it was edited by Maude White, an African American Communist and organiser until July 1934, and the radical African American lawyer and Communist 
Benjamin Davis). Originally called The Liberator the newspaper changed its name twice - to the Harlem Liberator in 1933 and to the Negro Liberator in 1934. It is named in this volume as The [Harlem/ Negro] Liberator to avoid confusion with The Liberator [1918-24]. The Liberator [1918-1924] an important and influential monthly socialist magazine which attracted some of the finest writers on the Left in the USA. It was edited by the Socialist Max Eastman and coedited for a time by the Jamaican writer Claude McKay. It became a Communist Party publication in 1922.

The Messenger [1917-1928] a monthly newspaper founded and edited by A. Philip Randolph and Chandler Owen. Randolph was the most successful black trade unionist of the period, founding the Brotherhood of Sleeping Car Porters and Maids in 1925. He joined the Socialist Party in 1910 and his antipathy towards the Communist Party becomes more pronounced in the early 1920s. Chandler Owen joined the Socialist Party in 1916 though by the end of the 1920s he had become a member of the Republican Party.

Negro World [1918-1933] was the official organ of Garvey's United Negro Improvement Association. Its early issues were decidedly more influenced by left-wing politics though, as Chapter 4 details, relationships between Garvey and other black activists disintegrated swiftly in the early 1920s.

Negro Worker [1928-1937] was a monthly journal of the International Trade Union Committee for Negro Workers (ITUCNW). It was edited by George Padmore from 1931-1934, and attempted to provide an internationalist vision of both pan-African and interracial anti-colonial struggle.

The radical press of the time was gloriously unstandardised in terms of spelling and punctuation. To maintain clarity throughout I have corrected minor errors in spelling, otherwise the texts are reproduced as they were at the time. Certain articles have been abridged, this is clearly signposted in the extracts themselves. 